\title{
The impacts of Seroja Tropical Cyclone towards extreme weather in East Nusa Tenggara
}

\author{
Andung Bayu Sekaranom ${ }^{1,2, *}$, Narastravika Henardi Putri ${ }^{2}$, and Fatih Cinderaswari Puspaningrani ${ }^{1}$ \\ ${ }^{1}$ Research Center for Disaster, Universitas Gadjah Mada, Yogyakarta-Indonesia \\ ${ }^{2}$ Department of Environmental Geography, Faculty of Geography, Universitas Gadjah Mada, Yogyakarta-Indonesia
}

\begin{abstract}
This paper aims to discuss the Seroja Tropical Cyclone and its impact on extreme weather. Seroja tropical cyclones occur from April 4 to 5th 2021, in the East Nusa Tenggara (NTT) region. Based on data from the Meteorology, Climatology and Geophysics Agency (BMKG), the initial position of the Seroja tropical cyclone was in the Savu Sea, southwest of Timor Island. Since April 1, 2021, the NTT region has become the center of low pressure that triggers the formation of this cyclone. When a tropical storm occurs, the intensity of rainfall which initially reaches less than $60 \mathrm{~mm} /$ day, increases rapidly to more than 100 $\mathrm{mm} /$ day on April 4 to 5, 2021. This is the impact of the low-pressure center that triggers the formation of tropical cyclones in the region.
\end{abstract}

\section{Introduction}

Weather conditions in Indonesia are influenced by various factors, including tropical cyclones [1]. Tropical cyclones have a direct impact on the areas as well as the surrounding [2]. Tropical cyclones also cause flooding due to increased rainfall. Tropical cyclones have different effects on rainfall depending on the characteristics of the cyclones and environmental conditions [3]. Tropical cyclones are one of the atmospheric phenomena that occur due to transferring heat from the equator to the higher latitudes, characterized by low air pressure that triggers strong winds. Tropical cyclones can impact increased rainfall, flood disasters, and damage to infrastructure over coastal and land areas [4]. Tropical cyclones cause destructive winds to areas with a distance of 250 miles or $155 \mathrm{~km}$ from the cyclone center, with wind speeds reaching $150 \mathrm{miles} /$ hour or $93 \mathrm{~km} /$ hour [5]. Tropical cyclones form over large oceans with a sea surface temperature of at least $26.5^{\circ} \mathrm{C}$ [6]. Tropical cyclones have varying durations ranging from a few hours to 14 days with an average of 6 days. The process starts from the tropical cyclone formation stage to the death stage when moving towards land or turning into subtropical areas [7].

The formation of tropical cyclones is supported by several atmospheric conditions, such as warm sea surface temperature, atmospheric instability, and high humidity in the lower to intermediate layers of the atmosphere. The Coriolis force also can maintain low pressure at its center, combined with pre-existing atmospheric disturbances and vertically low shear winds. Tropical cyclones develop near the equator and then move further from the equator. Tropical cyclones that form in the northern hemisphere move west or northwest, while tropical cyclones that form in the southern hemisphere move west or southwest. Tropical cyclones usually form over warm tropical waters [8].

Previous researches have identified some phenomena where tropical cyclone affect areas closer to the equator $[1,3]$. This is extremely rare condition since tropical cyclone often develop further, particularly at $10^{\circ}$ latitude or higher. Therefore, there is a gap of reseach question why this tropical cyclone develop closer to the equator. This information is crucial in prediction the future condition whether tropical cyclone tends to develop close to the equator. This paper aims to identify the characteristics of Seroja Tropical Cyclones occurring from April 4 to 5, 2021, in the East Nusa Tenggara (NTT) region. Based on data from the Meteorology, Climatology and Geophysics Agency (BMKG), the position of Seroja Tropical Cyclones is in the Savu Sea, southwest of Timor Island. BMKG stated that this tropical cyclone caused an increase in rainfall around the cyclone and extreme weather in NTT. The increase in rainfall with moderate to high intensity causes flash floods in the region. Therefore, this study is important to develop disaster mitigation and adaptation plans in the future.

\section{Data and method}

The analysis presented in this paper is based on nearreal-time data immediately after the Seroja Tropical Cyclone. The data used is mainly data from satellitebased rainfall estimation products. The use of satellite estimation rainfall data is selected because it can produce fast information immediately after the event occurs [9]. Although there are differences in rainfall

\footnotetext{
* Corresponding author: andungnbayu@geo.ugm.ac.id
} 
based on estimates of weather satellites and meteorological stations due to differences in measurement principles, the results of these satellite rainfall estimates are not much different from meteorological station data $[10,11]$. This is supported by the characteristics of the study area, which are affected by the Southeast Asian Monsoon, where the rainy season occurs between November-May and the dry season occurs between June-October. In general, satellite-based rainfall estimates in Indonesia will be higher in areas affected by monsoons than in areas near the equator with two rain peaks and areas affected by local circulation [12-14].

The stages carried out in the analysis consisted of two steps, namely 1) Analysis of extreme rainfall and 2) Estimating the impact caused by the sacred tropical cyclone. Satellite rainfall estimation data from the GSMaP product (https://sharaku.eorc.jaxa.jp/GSMaP/) were used to analyze the impact of Seroja Tropical Cyclones on extreme rainfall. The product used is daily data derived from near-real-time products (GSMaP NRT). The analysis time used is from March 29, 2021, to April 11, 2021. The average rainfall calculation is based on landfalling precipitation in a bounding box between 118.5 to 125.5 degrees longitude and 7.5 to 12.5 degrees latitude. The estimation of the impact caused by the Seroja tropical cyclone was carried out based on the publication of data from the National Disaster Management Agency of Indonesia (BNPB) and releases from the mass media shortly after the cyclone occurred. Data processing at both stages is carried out using geographic information system (GIS) software.

\section{Extreme precipitation due to the Seroja Tropical Cyclone}

During the last seven days before Seroja Tropical Cyclone was formed, the East Nusa Tenggara (NTT) region tended to have a warmer sea surface temperature than the surrounding areas. This condition indicates the amount of convective activity that triggers the formation of rain clouds. Warm sea surface temperatures also support atmospheric conditions when tropical cyclones occur. Since April 1, 2021, the NTT region has become the center of low pressure. This is based on the air pressure in the NTT region ranging from 1006-1008 mb and continues to decline until it reaches the Tropical Depression of $994 \mathrm{mb}$ on April 4, 2021. Seroja tropical cyclones, which have air pressure reaching $994 \mathrm{mb}$ according to the Saffir-Simpson scale, are included in the minimal category. The maximum wind speed is estimated to be between $33-42 \mathrm{~m} / \mathrm{s}$. Seroja tropical cyclones fall into the 1st category where the wind is classified as dangerous and can cause damage to the exterior of a well-constructed house, uproot small trees, break tree branches, and cause damage to the power grid.

As the wind moves from the center of high pressure to the center of low pressure in the south part of the study area, the center of low-pressure depression then turns into a tropical cyclone. The lower air pressure makes air masses tend to gather, resulting in heavy rains and the potential to cause flooding in the NTT region. BMKG stated that this sacred tropical cyclone caused an increase in rainfall around the cyclone and extreme weather in NTT. The increase in rainfall with moderate to high intensity causes flash floods in NTT. This is also indicated by the high amount of rainfall on April 4 to 5, 2021, based on the Global Satellite Mapping of Precipitation (GSMaP) rainfall data, as shown in Figure 1.

Figure 1 shows that the rainfall in NTT is high during the Seroja Tropical Cyclone. It can be seen that the rainfall has continued to increase during the last few days before the occurrence of a tropical cyclone, but this increase is not significant and volatile. When a tropical cyclone occurs, the intensity of rainfall which initially reaches less than $60 \mathrm{~mm} /$ day, increases rapidly to reach more than $100 \mathrm{~mm} /$ day on April 4 to 5, 2021. This happens as an impact of the low-pressure center that triggers the formation of cyclones. Tropical cyclones then move away from the study area and reduce their impact on rainfall starting April 6, 2021. From April 6, 2021, rainfall seems to have decreased even closer to 0 $\mathrm{mm} /$ day (no rain). This shows that the cyclone has moved away from the region where rainfall has returned to a significant decline. Spatially, the distribution of rainfall can be seen in Figure 2 and Figure 3.

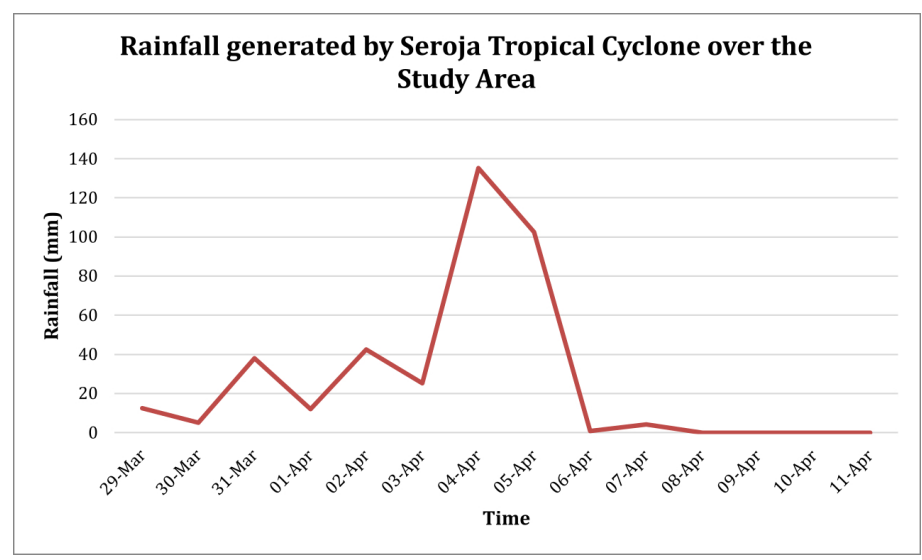

Fig. 1. Graph of rainfall in East Nusa Tenggara (source: results of GSMaP rainfall estimation data processing in 2021) 


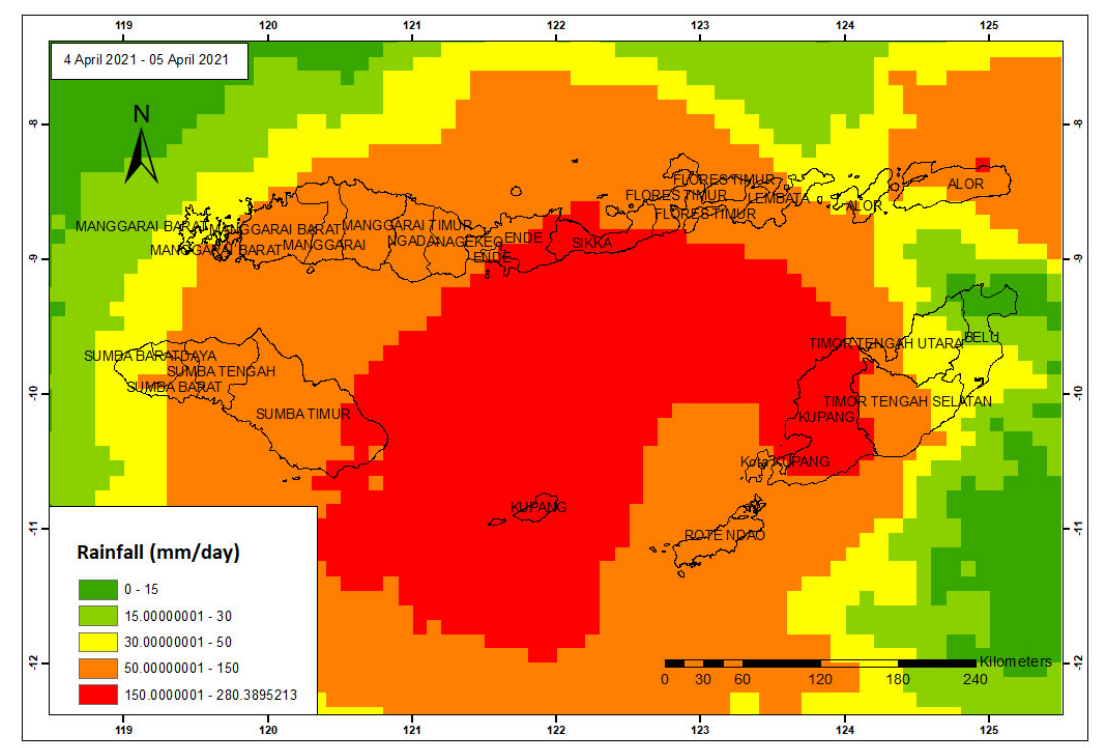

Fig. 2. Spatial distribution of rainfall in East Nusa Tenggara, April 4-5, 2021 (source: results of GSMaP rainfall estimation data processing for 2021)

From Figure 2, it can be seen that on April 4 to 5, 2021, high to very high concentrations of rainfall occurred in districts/cities adjacent to the Savu Sea as the center for the formation of the tropical cyclone. Districts with very high rainfall are Sabu Raijua, Kupang, most of Sikka and Ende, and a small part of East Sumba and South Central Timor. Districts / cities with high rainfall are Rote Ndao, Kupang, East Flores, Ngada, East Manggarai, Manggarai, Central Sumba, West Sumba, most of West Manggarai, Lembata, South Central Timor, East Sumba, a small part of Ende and North Central Timor District.
The Seroja Tropical Cyclone that begins to move away to the southwest as associated with decreasing rainfall, as shown in Figures 3, impacts rainfall in the area around the center of the cyclone formation. In contrast to Figure 2, the rainfall on April 6 to 7, 2021, is classified as low and even very low with a rainfall intensity of less than $15 \mathrm{~mm} /$ day. During that time, the cyclone had moved to the southwest, away from the NTT region. This is because tropical cyclones in the southern hemisphere tend to move west or southwest and away from the equator. Rainfall on April 6 to 7, 2021, can be seen spatially in Figure 3.

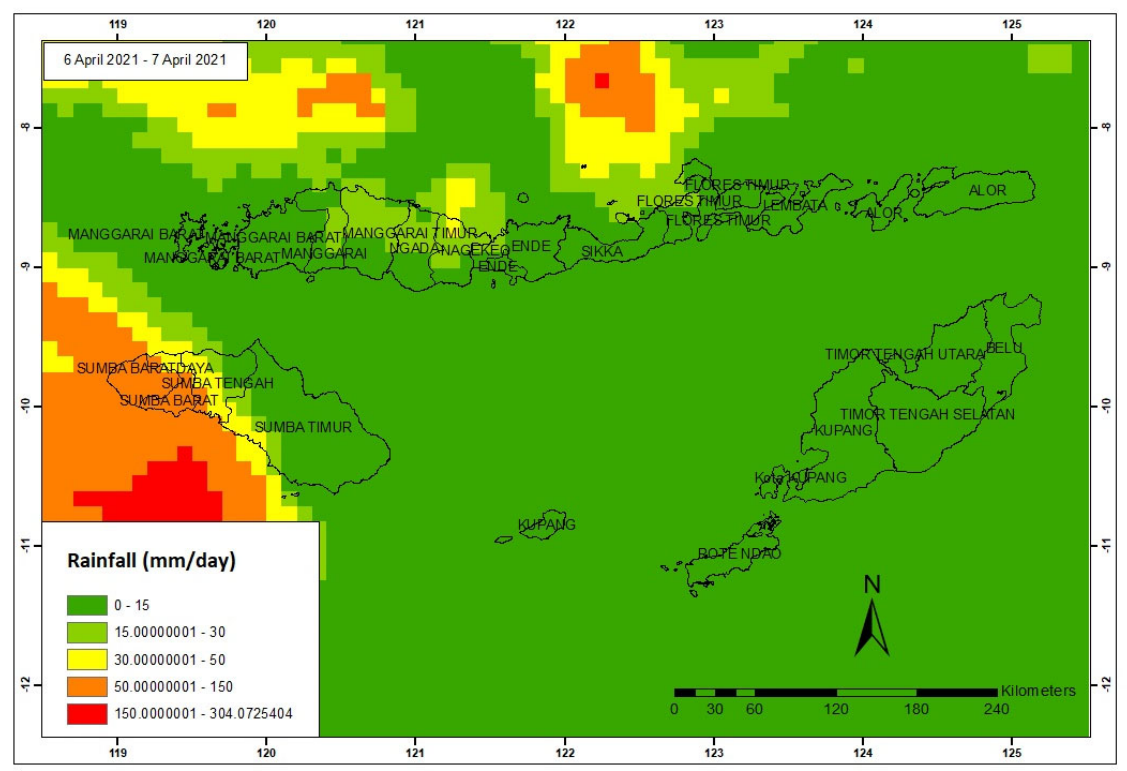

Fig. 3. Spatial distribution of rainfall in East Nusa Tenggara, April 6-7, 2021 (source: results of GSMaP rainfall estimation data processing for 2021) 
Based on Figure 3, most rainfall in the NTT region shows a very low rainfall intensity $(0-15 \mathrm{~mm} /$ day $)$. In some areas, including Sumba Tengah, Manggarai Tengah, Manggarai Timur, and Ngada, they have low to moderate rainfall. High rainfall with an intensity of 50$150 \mathrm{~mm}$ / day is only found in parts of Southwest Sumba and West Sumba. This indicates that the Seroja Tropical Cyclone has a considerable impact on weather conditions in NTT. Rainfall after a cyclone is classified as low and has a much different intensity than at the cyclone time. As seen in Figure 5, from April 6 to 7, 2021, high to very high rainfall is in the southwestern region of NTT. It then moves following the movement to the southwest.

\section{Damage estimation}

Apart from heavy rains, cyclones can also cause storm surges and winds that lead to disasters [15]. Tropical cyclones cause enormous impacts such as strong winds and heavy rain, which can cause flooding, high waves, and storm surges or storm surges in the areas they pass through. According to BMKG, Seroja tropical cyclones have the opportunity to cause sea waves to be more than six meters high in the southern part of the study area. Districts/cities affected by the tropical cyclone of Seroja according to BNPB include the City of Kupang, West Sumba, East Sumba, Kupang,
South Central Timor, Belu, Ngada, Alor, Lembata, East Flores, Sikka, Ende, Rote Ndao, Sabu Raijua, and Malacca Regency. More details on the areas affected by the Seroja tropical cyclone can be seen in Figure 4.

Seroja tropical cyclones cause rain to occur continuously and result in flash floods in East Nusa Tenggara (NTT). The disaster caused significant casualties, damage to buildings, and economic losses. Due to this disaster, the number of victims has continued to increase for about a week since the disaster. Based on data compiled from publications by the official BNPB and several other mass media sources, as of April 18, 2021, 181 people died, 225 injured victims, and 48 missing victims. Meanwhile, 13050 people were displaced, with 428,986 affected residents. The number of dead, missing, and displaced victims in detail can be seen in Table 1.

Seroja tropical cyclones, apart from causing casualties, also caused damage to buildings in various locations. Based on data collected from BNPB as well as information from online mass media, up to April 18, 2021 , it is estimated that the number of damaged houses in the NTT region will reach more than 66,000 housing units. 17,124 units of houses were severely damaged, 13,652 units moderately damaged, and 35,733 units slightly damaged. The composition of severely damaged houses, moderately damaged, and slightly damaged were $26 \%, 21 \%$, and $54 \%$ of the total houses affected by the disaster, respectively, or can be seen in Table 2 .

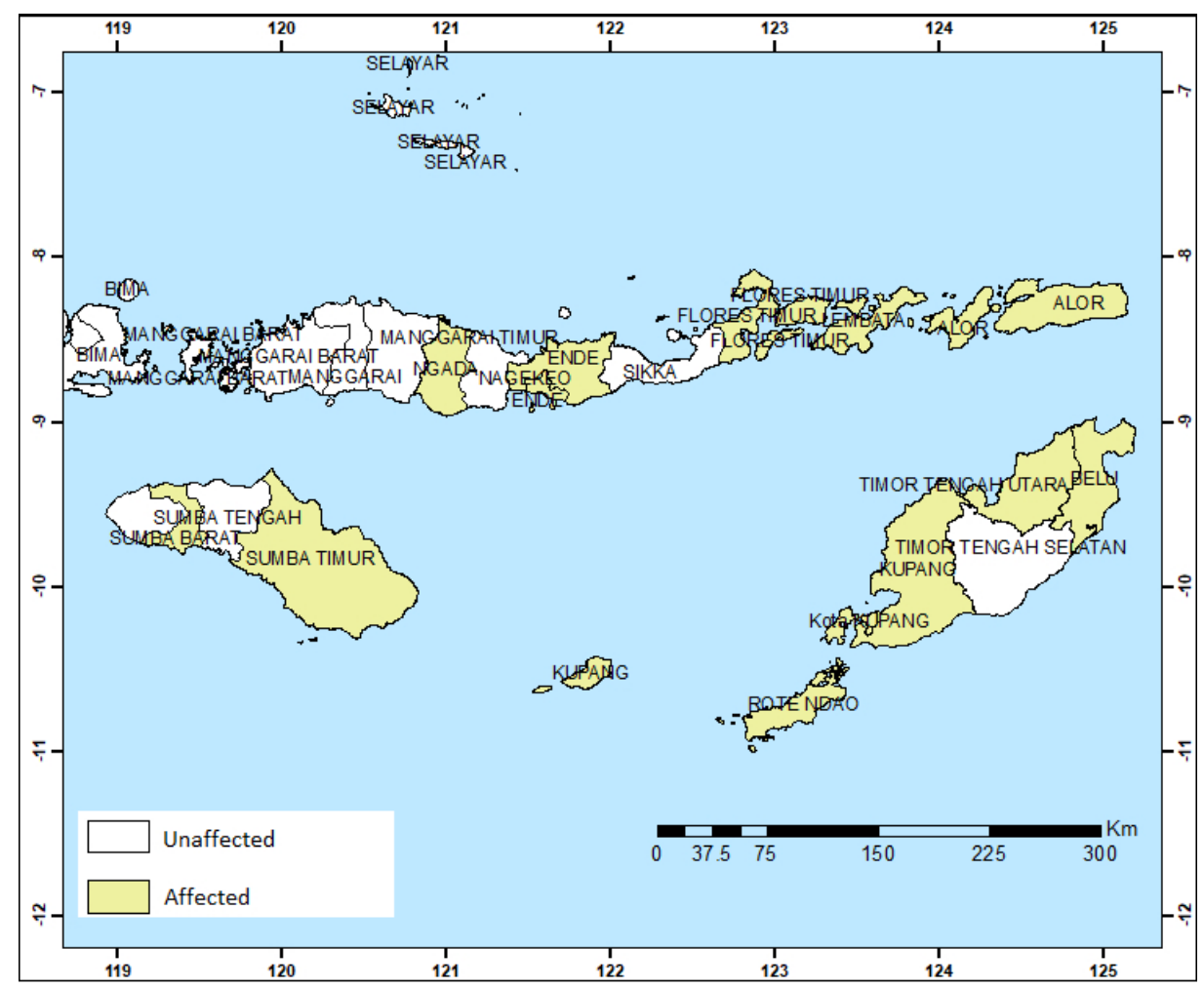

Fig. 4. Map of disaster affected areas due to Seroja Tropical Cyclone (source: results of BNPB data processing in 2021) 
Table 1. Number of affected person due to Seroja Tropical Cyclone (source: data processing of BNPB and mass media reports)

\begin{tabular}{|l|r|r|r|r|}
\hline \multirow{2}{*}{ Districts/Cities } & \multicolumn{4}{|c|}{ Person affected } \\
\cline { 2 - 5 } & Death & Injured & Losses & Evacuated \\
\hline Kota Kupang & 6 & 8 & 1 & 265 \\
\hline $\begin{array}{l}\text { Kabupaten } \\
\text { Sumba Barat }\end{array}$ & - & - & - & 284 \\
\hline $\begin{array}{l}\text { Kabupaten } \\
\text { Sumba Timur }\end{array}$ & - & - & - & 570 \\
\hline $\begin{array}{l}\text { Kabupaten } \\
\text { Kupang }\end{array}$ & 12 & 26 & 3 & 1698 \\
\hline $\begin{array}{l}\text { Kabupaten } \\
\text { Timor Tengah } \\
\text { Selatan }\end{array}$ & - & - & - & 690 \\
\hline Kabupaten Belu & - & - & - & 644 \\
\hline $\begin{array}{l}\text { Kabupaten } \\
\text { Ngada }\end{array}$ & - & 3 & - & - \\
\hline Kabupaten Alor & 28 & 25 & 13 & - \\
\hline $\begin{array}{l}\text { Kabupaten } \\
\text { Lembata }\end{array}$ & 46 & 53 & 22 & 1146 \\
\hline $\begin{array}{l}\text { Kabupaten } \\
\text { Flores Timur }\end{array}$ & 72 & 76 & 2 & 2118 \\
\hline $\begin{array}{l}\text { Kabupaten } \\
\text { Sikka }\end{array}$ & 1 & - & - & - \\
\hline Kabupaten Ende & 1 & - & - & 20 \\
\hline $\begin{array}{l}\text { Kabupaten Rote } \\
\text { Ndao }\end{array}$ & 1 & 34 & - & 5556 \\
\hline $\begin{array}{l}\text { Kabupaten Sabu } \\
\text { Raijua }\end{array}$ & 3 & - & 7 & 59 \\
\hline $\begin{array}{l}\text { Kabupaten } \\
\text { Malaka }\end{array}$ & 11 & - & - & - \\
\hline Total & $\mathbf{1 8 1}$ & $\mathbf{2 2 5}$ & $\mathbf{4 8}$ & $\mathbf{1 3 0 5 0}$ \\
\hline
\end{tabular}

Tabel 2. Number of damaged building due to Seroja Tropical Cyclone (source: data processing of BNPB and mass media reports)

\begin{tabular}{|c|c|c|}
\hline $\begin{array}{c}\text { level of } \\
\text { damages }\end{array}$ & Unit & $\begin{array}{c}\text { Percentage } \\
(\%)\end{array}$ \\
\hline High & 17124 & 26 \\
\hline Medium & 13652 & 21 \\
\hline Low & 35733 & 54 \\
\hline Total & $\mathbf{6 6 5 0 9}$ & $\mathbf{1 0 0}$ \\
\hline
\end{tabular}

The damage to buildings caused by the cyclone is limited to houses belonging to residents and facilities and infrastructure for residential areas, including damage to roads, bridges, electricity networks, telephone and internet networks. In addition, there was damage to other buildings, both private and government-owned. However, the condition of the houses and other buildings is not yet known in detail the extent of the damage so that the number of material losses from building damage cannot be ascertained. In Kota Kupang, the loss was estimated at 47 billion rupiahs. In Lembata Regency, at least 70 families lost their agricultural land, lodgings in plantation locations, and dozens of livestock that were swept away by the floods so that the losses were estimated at hundreds of millions of rupiah. In Kupang Regency, the fisheries and tourism sectors suffered considerable losses, including failed seaweed harvests reaching 7 billion rupiahs, damage to fishing boats reaching 780 million rupiahs, and damage to tourism facilities reaching 100 million rupiahs. The losses caused by the tropical cyclone of Seroja in the Rote Ndao Regency have primarily occurred in the productive economic sector, including agriculture and fisheries. In the agricultural sector, the damage to rice fields covering an area of 1800 hectares is estimated at 71 billion rupiahs. In the fisheries sector, damage to docks and boats and lost boats reached 141 billion rupiahs.

The data above shows an example of the significant impact of a catastrophic event caused by a tropical cyclone. Although the center of a tropical cyclone is not on land, the tail of the sacred tropical cyclone brings 
extreme rainfall. The analysis results show that during the formation of Seroja tropical cyclones, rainfall reached extreme levels above $100 \mathrm{~mm} /$ day for two consecutive days. Compared with the average monthly rainfall during the rainy season, which is generally only 150 to $300 \mathrm{~mm} / \mathrm{month}$, the total rain received during these two days almost matches the monthly rainfall. This, of course, has an impact on the surface hydrology system, which very rarely receives rainfall of this magnitude. In this case, the characteristics of the watershed also contributed to the occurrence of flash floods, which resulted in the death toll of more than 200 people and economic losses of up to billions of rupiahs.

\section{Conclusions}

Disaster events induced by tropical cyclones in Indonesia still have the potential to occur in the future. Although tropical cyclones tend to form in areas about $10^{\circ}$ to $15^{\circ}$ degrees from the equator and move away, their tails can carry enough moisture to trigger extreme rain, likewise for the case of Seroja Tropical Cyclone, which formed around the East of Rote Island about $10^{\circ} \mathrm{S}$ in latitude. Several tropical cyclones formed at a latitude of about $10^{\circ} \mathrm{S}$ have also impacted the occurrence of flash floods and landslides in southern Indonesia, for example, Cempaka and Dahlia Cyclones in 2017.

Tropical cyclones can form due to an increase in sea surface temperature. As a result, the air temperature in the lower atmosphere is getting warmer, followed by an increase in humidity which triggers a low pressure center followed by high rainfall. Climate change in the form of a global temperature increase will theoretically result in a lower frequency of tropical cyclones due to a reduced temperature gradient between the air near the surface and the layer above it. However, the strength of cyclones (in the form of wind speed and rainfall) will increase over time because warmer waters contain a more significant energy content in the form of heat. The potential for the formation of tropical cyclones is also predicted to shift closer to the equator as the earth's temperature increases due to climate change [12].

The impact of potential disasters due to tropical cyclones needs to be minimized. An example is by carrying out disaster risk mapping and educating people in disaster-prone areas. The first for coastal areas is the danger of storm surge due to tides accompanied by increased wind speed. The high wave early warning system is beneficial so that local populations/fishermen stay away from activities around the coast. The existence of coastal protection plants is also beneficial for reducing increased abrasion due to storm surges. For areas further inland, extreme rainfall is a significant concern. Extreme rainfall can cause flooding and trigger landslides, such as in the 2017 Cempaka tropical cyclone in Pacitan - Central Java. Mitigation efforts, in this case, need to pay attention to watershed ecosystems. They were mainly related to forest conservation which has the function of water regulation and preventing landslides.

This publication is supported by grants of "Hibah Desentralisasi Penelitian Dasar Perguruan Tinggi (PDUPT)" by Directorate of Higher Education, Indonesian Ministry of Education. The grant entitled "Optimization of Rainfall Estimation Products based on Characterization of Precipitation Organization" (contract number 1632/UN1/DITLIT/DIT-LIT/PT/2021) with Dr. Andung Bayu Sekaranom as principal investigator.

\section{References}

1. S. H. J. Tongkukut, W. L. Kawuwung, S. Sutikno, Jurnal MIPA Universitas Sam Ratulangi, 8, 21-27 (2019)

2. N. S. Haryani, Zubaidah, Jurnal Ilmiah Widya, 29, 54-58 (2012)

3. R. Prasetya, A. As'ari, W. Dayantolis, Jurnal Fisika Dan Aplikasinya, 10, 1-9 (2014)

4. D. Surinati, D.A. Kusuma, Oseano, 43, 1 - 12 (2018)

5. A. Suryantoro, Majalah Sains dan Teknologi Dirgantara, 3, 21-32 (2008)

6. M.D. Syaifullah, Jurnal Sains dan Teknologi Modifikasi Cuaca, 16, 61 - 71 (2015)

7. N. Dyahwathi, S. Effendy, E. Adiningsih, Agromet, 21, 61-72 (2007)

8. A. M. Dewi, A. Kristianto, Jurnal Meteorologi Klimatologi dan Geofisika, 4, 8-16 (2017)

9. A. B. Sekaranom, H. Masunaga, J. Appl. Meteorol. Climatol., 56, 1867-1881 (2017)

10. A. B. Sekaranom, H. Masunaga, J. Appl. Meteorol. Climatol., 58, 37-54 (2019)

11. A. B. Sekaranom, E. Nurjani, M. P. Hadi, M. A. Marfai, Quaest. Geogr., 37, 97-114 (2018)

12. A. B. Sekaranom, E. Nurjani, R. Harini, A. S. Muttaqin, Indones. J. Geogr., 52, 143-153 (2020)

13. A. B. Sekaranom, E. Nurjani, The development of Articulated Weather Generator model and its application in simulating future climate variability, in proceeding of IOP Conference Series: Earth and Environmental Science, 256 (2019)

14. A. B. Sekaranom, E. Nurjani, I. Pujiastuti, Cloud structure evolution of heavy rain events from the East-West Pacific Ocean: A combined global observation analysis, in proceeding of IOP Conference Series: Earth and Environmental Science, 148 (2018)

15. H. Xu, X. Zhang, $\mathrm{X} . \mathrm{Xu}$, Advances in Meteorology, 13, 1-13 (2013) 